\title{
Refractory overactive bladder: a common problem?
}

\author{
Ulrich Schwantes • Joachim Grosse • \\ Andreas Wiedemann
}

Received: 22 October 2014 / Accepted: 24 February 2015 / Published online: 20 March 2015

(C) The Author(s) 2015. This article is published with open access at Springerlink.com

\begin{abstract}
Introduction and hypothesis Unsatisfactory treatment outcome sometimes is described as frequently occurring in patients treated with first-line therapy for overactive bladder (OAB). The present article reviews the different circumstances which may result in failure to respond to lifestyle interventions, behavioral therapy, and/or antimuscarinic treatment.

Methods An extensive literature search was conducted to identify relevant articles on pathophysiological, clinical, and pharmacological aspects of refractory OAB.

Results Missing definition, unrealistic individual expectation of treatment outcomes, lack of communication between physician and patient as well as pathophysiological and pharmacological processes were identified as relevant for failure to respond to first-line OAB treatment. Increase of patient's motivation to adhere to the prescribed treatment, critical examination of the patient in regard to the initial diagnosis, and individual adjustment of antimuscarinic therapy may be appropriate tools to improve treatment outcome in OAB patients.

Conclusions Overall, the incidence of refractory OAB seems to be overestimated. There are several approaches to improve therapy results.
\end{abstract}

\footnotetext{
U. Schwantes $(\bowtie)$

Department of Medical Science/Clinical Research, Dr. R. Pfleger

GmbH, 96045 Bamberg, Germany

e-mail: ulrich.schwantes@dr-pfleger.de

J. Grosse

Urological Clinic, University Clinic Aachen,

52074 Aachen, Germany

e-mail: jgrosse@ukaachen.de

\author{
A. Wiedemann \\ Department of Urology, Evangelisches Krankenhaus Witten \\ gGmbH, University Witten/Herdecke, 58455 Witten, Germany \\ e-mail: awiedemann@diakonie-ruhr.de
}

Keywords Refractory OAB · Treatment · Antimuscarinic . Pathophysiology $\cdot$ Pharmacology

\section{Introduction}

Lifestyle interventions and behavioral therapies, which may be combined with antimuscarinic treatment, are recommended in international guidelines as first-line therapy for patients with overactive bladder (OAB) $[1,2]$. Failure to respond to conservative and pharmacological treatment of OAB has previously been described [3], but there is considerable heterogeneity in the definitions of both treatment response and nonresponse in trials involving patients with OAB [4]. Over the last few years several clinical studies have been published which investigated different pharmacological principles (e.g., other antimuscarinic drugs, beta-3 agonists, botulinum toxin) and strategies (increasing anticholinergic doses, additional treatment with other anticholinergic drugs, or beta-3 agonists) in the treatment of patients with refractory $\mathrm{OAB}$ [5-10]. The vast majority of these studies report significant improvement of $\mathrm{OAB}$ symptoms following a change in treatment. In this review we discuss published data concerning factors which may be behind refractory $\mathrm{OAB}$ in order to aid in understanding different treatment results in $\mathrm{OAB}$ patients.

\section{Materials and methods}

Computerized library systems such as MEDLINE, BIOSIS, and EMBASE were analyzed regarding articles on refractory OAB published between 2000 and 2014. Search terms included "overactive bladder" or "detrusor overactivity" or "antimuscarinic" AND "non-responder," or "refractory," or "fail," or "persistent," or "dissatisfied." Furthermore, reviews 
of pharmacological and physiological aspects were carried out using the same first two search terms combined with terms such as "muscarinic," "nicotinic," "m-receptor," "adrenergic, " and "transporters." In addition, unpublished pharmacological and clinical data were included.

\section{Results}

The missing definition

Refractory $\mathrm{OAB}$ patients most likely represent a minority of the total $\mathrm{OAB}$ population, but the epidemiology is unknown [11]. As shown by Goldman et al., a wide variety of symptombased definitions and patient-reported outcomes with inconsistent thresholds are used in the published literature to decide whether or not patients respond to conservative and/or antimuscarinic treatment [4]. Moreover, patients' individual evaluation of treatment success is characterized by different expectations and perceptions [4]. Accordingly, patients' statements on failure of antimuscarinic treatment are diverse. A large-scale study involving 5,392 patients showed that $46.2 \%$ of those who reported discontinuing one or more antimuscarinic $\mathrm{OAB}$ medications gave the reason for this that the treatment "did not work as expected," in $25.1 \%$ medication was switched, $23.3 \%$ "learned to get by without medication," and $21.1 \%$ discontinued due to side effects [12]. The current American Urological Association (AUA) and European Association of Urology (EAU) guidelines on urinary incontinence contain recommendations for the treatment of refractory $\mathrm{OAB}[1,2]$, but no definitions of criteria and/or thresholds to assess unsatisfactory outcomes of therapy were described.

\section{Physician's expectations}

Current clinical studies in patients with refractory $\mathrm{OAB}$ whose behavioral and/or antimuscarinic treatment was stopped due to lack of efficacy or side effects and replaced by alternative medication (e.g., botulinum toxin $\mathrm{A}$, other antimuscarinics, beta-3 agonists) are summarized in Table 1. When assessing the results of these studies concurrently, it becomes clear that definitions of "antimuscarinic failure" are based on inconsistent criteria ranging from the somewhat subjective evaluation "lack of benefit or intolerable side effects" to the strict prerequisite of " $\geq 1 \mathrm{UUI} /$ day." This corresponds with the observations made by Goldman et al. in their systematic review [4]. If the criteria for diagnosis of refractory $\mathrm{OAB}$ used in these studies are compared with those defined for success in the changed treatment studies (Table 1), it becomes obvious that the latter criteria often seem to be less strict [6,13-15]. If the same strict criteria of $>1$ UUI day, as was chosen for inclusion into the study by Kanagarajah et al. [15] and Kuo [13], had been defined as the response following secondary therapy, practically no patients could be classified as a responder in the described clinical studies with botulinum toxin A. This demonstrates that the physician's individual expectations may be highly relevant in differentiating between responders and nonresponders to primary $\mathrm{OAB}$ treatment. In practice, complete cure of $\mathrm{OAB}$ symptoms under first-line treatment is rare [16], and even after second-line treatment with botulinum toxin and neuromodulation the proportion of patients showing improvement of symptoms rather than total cure is greater $[17,18]$.

Patients' motivation and expectations

Essential for treatment response to OAB treatment is adherence to the prescribed therapy. Although it seems mundane, during both conservative and antimuscarinic treatment, realistic information provided to the patient on possible treatment efficacy, and on side effects, and additionally the quality of the course for lifestyle modification and behavioral bladder retraining, are essential to reach adherence to the prescribed treatment $[1,16]$. Lifestyle modification should include stopping smoking and limiting the intake of caffeine, alcohol, and carbonated and citrus beverages, which may lead to an increase in OAB symptoms $[16,19]$.

Indeed, inadequate follow-up after initiation of therapy (poor motivation) and unmet or unrealistic expectations (poor communication between patients and the physician) have been identified as contributory factors to nonadherence, in addition to adverse events and insufficient beneficial effects [20]. Jundt et al. demonstrated in their survey that $10 \%$ of patients with $\mathrm{OAB}$ had not started with the medication 12 months after prescription because of their "fear of side effects" or did "not want to take pills" [21]. In this study, most patients stopped taking the medication without discussing the issue with their doctor. Swartz and Vasavada assume that many patients may be prematurely labeled as having refractory $\mathrm{OAB}$ after only a modest attempt at medical or behavioral treatment [11]. Consequently, regular follow-ups to monitor treatment effects and adherence may be useful [16] as well as providing realistic information on symptom improvements as expected treatment success and on any side effects which may occur.

Pathophysiological reasons

$\mathrm{OAB}$ is a symptom complex rather than a disease. Lack of efficacy of treatment with antimuscarinics as well as with behavioral bladder retraining, may be associated with underlying causes for lower urinary tract dysfunction which may have been overlooked in previous examinations. In order to exclude any other causes, repeated examinations of bacterial cystitis, painful bladder, voiding dysfunction, bladder or pelvic tumors, calculus, atrophic vaginitis, vaginal prolapse, 


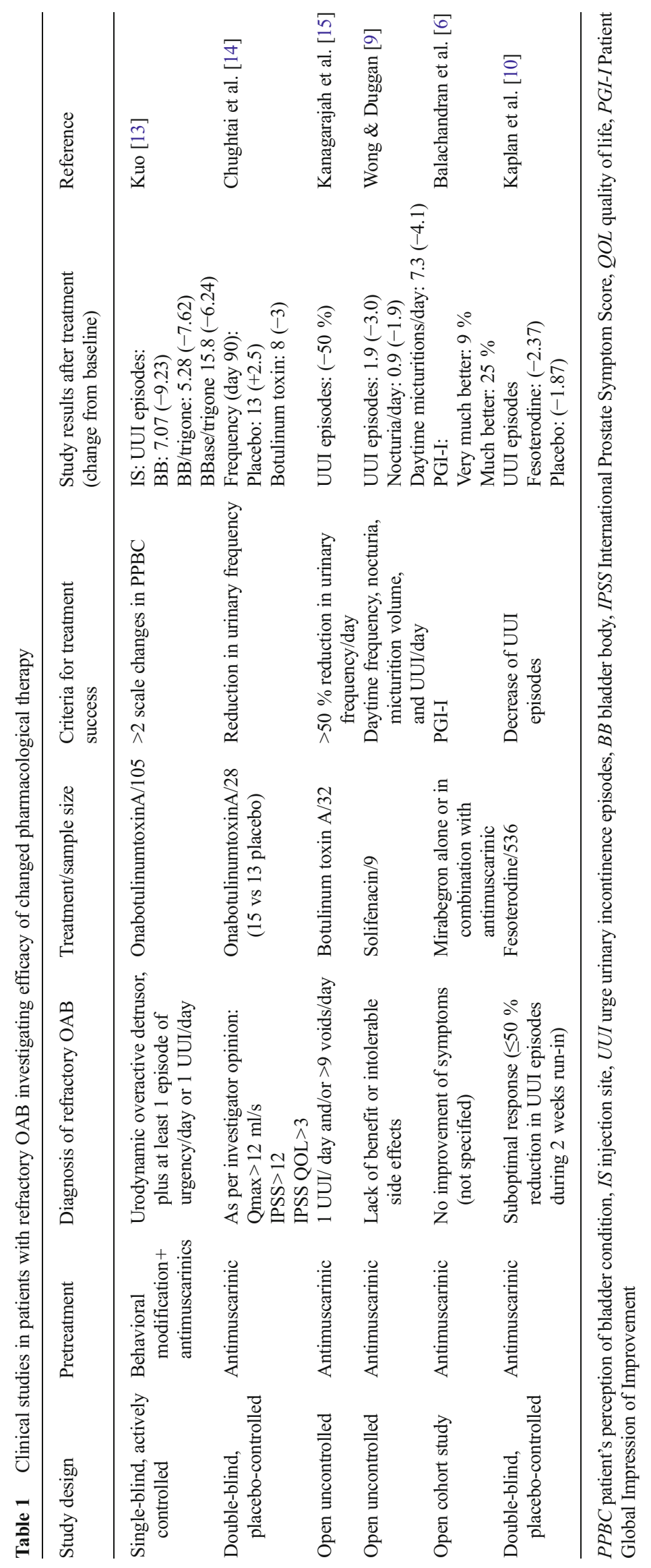


medication side effects, neurological reasons, polyuria (polydipsia, diabetes mellitus/insipidus, chronic renal failure, and hyperthyroidism) should be considered [1, 22, 23].

Digesu et al. investigated 110 women with refractory $\mathrm{OAB}$ by cystoscopy and biopsy [24]. The patients had undergone conservative management (lifestyle change, bladder retraining, and physiotherapy) and previous treatment with two or more antimuscarinics. Among the patients, histopathology showed chronic cystitis in 94, follicular cystitis in 3, acute and chronic cystitis in 2 , transitional cell carcinoma in 6 , and no abnormality in 1 , suggesting that $\mathrm{OAB}$ refractory to antimuscarinics may be caused by chronic inflammation.

Evidence that inflammatory processes are involved in the pathogenesis of refractory $\mathrm{OAB}$ emerged from the investigations by the research group of Kuo who found that the inflammatory markers serum nerve growth factor (NGF), C-reactive protein, and adipokines including interleukins and tumor necrosis factor are increased in patients with refractory $\mathrm{OAB}[13$, $25,26]$. Interestingly, elevated urinary NGF levels decreased significantly in 39 women with refractory OAB after antibiotic therapy, while the OAB symptoms daytime frequency, nocturia, and urgency simultaneously improved significantly [27]. Seventy four percent of these women also reported improvement in perception of their bladder condition.

\section{Pharmacological reasons}

\section{Pharmacokinetics}

After oral administration, bioavailability of the tertiary antimuscarinic drugs darifenacin, oxybutynin, fesoterodine, and tolterodine as well as of the quaternary drug trospium chloride is characterized by a high intersubject variability (Table 2) ([28-30], data on file 2013, Dr. R. Pfleger GmbH, Bamberg, Germany). In the case of the tertiary antimuscarinics, individual pharmacokinetics may vary due

Table 2 Intersubject variability of maximum plasma concentration $\left(\mathrm{C}_{\max }\right)$ and area under the curve (AUC) values of different antimuscarinic drugs under steady-state conditions

\begin{tabular}{|c|c|c|}
\hline & & Reference \\
\hline \multicolumn{3}{|l|}{ Variability of $\mathrm{C}_{\max }$ in $\%$} \\
\hline Fesoterodine ER & $33-48$ & Malhotra et al. [28] \\
\hline Tolterodine ER & $46-87$ & Malhotra et al. [28] \\
\hline Trospium chloride IR & $9-64$ & $\begin{array}{l}\text { Data on file } 2013 \text {, } \\
\text { Dr. R. Pfleger GmbH } \\
\text { Bamberg }\end{array}$ \\
\hline \multicolumn{3}{|l|}{ Variability of AUC in $\%$} \\
\hline Darifenacin ER & $\begin{array}{l}48-71 \%(\mathrm{EM}) \\
20-61 \%(\mathrm{PM})\end{array}$ & Skerjanec [29] \\
\hline
\end{tabular}

$E R$ extended release, $I R$ immediate release, $P M$ poor metabolizers, $E M$ extensive metabolizers to genetic differences resulting in dissimilar metabolic degradation by enzymes of the cytochrome P450 system [29, 31]. In contrast, variability of bioavailability of trospium chloride is primarily based on the relatively low rate of intestinal absorption [32], and excretion via bile and urine, where different drug carriers seem to be involved [33, 34].

Furthermore, the pharmacokinetics of some antimuscarinic drugs are influenced by food intake. Increased $\mathrm{C}_{\max }$ values of the active drug were observed when oxybutynin, darifenacin, and fesoterodine extended release were coadministered with a high-fat meal $[29,31,35]$, whereas decreased $C_{\max }$ and AUC values were calculated after ingestion of a high-fat meal together with trospium chloride [36].

Further factors which can influence the pharmacokinetics of antimuscarinics include age, gender, and race (Table 3) as well as hepatic and renal impairment. Since drug excretion via the kidneys declines with age, Turnheim recommends treating the elderly in general as renally insufficient patients [45].

\section{Interactions}

In addition to the described variations of the pharmacokinetics of antimuscarinics, interactions with other simultaneously taken drugs may lead to decreased or increased effects, thereby

Table 3 Influences of age, gender, and race on pharmacokinetics of different antimuscarinics used for $\mathrm{OAB}$

\begin{tabular}{|c|c|c|c|}
\hline $\begin{array}{l}\text { Factor } \\
\text { influencing } \\
\text { PK }\end{array}$ & $\begin{array}{l}\text { Antimuscarinic } \\
\text { drug }\end{array}$ & Influence & Reference \\
\hline \multirow[t]{6}{*}{ Age } & Darifenacin & Yes & Skerjanec [29] \\
\hline & Fesoterodine & No & Malhotra et al. [37] \\
\hline & Oxybutynin & $\begin{array}{l}\text { Increased } \\
\text { plasma levels }\end{array}$ & Hughes et al. [38] \\
\hline & Solifenacin & $\mathrm{AUC}+20 \%$ & Krauwinkel et al. [39] \\
\hline & Tolterodine & No & Wefer et al. [40] \\
\hline & $\begin{array}{l}\text { Trospium } \\
\text { chloride }\end{array}$ & No & Doroshyenko et al. [41] \\
\hline \multirow[t]{6}{*}{ Gender } & Darifenacin & $\begin{array}{l}\text { Lower CL } \\
\text { in women }\end{array}$ & Kerbusch et al. [42] \\
\hline & Fesoterodine & No & Malhotra et al. [37] \\
\hline & Oxybutynin & No & Lukkari et al. [43] \\
\hline & Solifenacin & No & Krauwinkel et al. [39] \\
\hline & Tolterodine & No & Guay [44] \\
\hline & $\begin{array}{l}\text { Trospium } \\
\text { chloride }\end{array}$ & No & $\begin{array}{l}\text { Data on file 2013, } \\
\text { Dr R. Pfleger GmbH }\end{array}$ \\
\hline \multirow[t]{3}{*}{ Race } & Darifenacin & $\begin{array}{l}\text { Japanese: } \\
\text { lower BA }\end{array}$ & Skerjanec [29] \\
\hline & Fesoterodine & Japanese & Malhotra et al. [37] \\
\hline & Tolterodine & $\begin{array}{l}\text { Whites: } \\
\text { AUC+10\% }\end{array}$ & Guay [44] \\
\hline
\end{tabular}

$P K$ pharmacokinetics, $B A$ bioavailability, $C L$ clearance 
possibly limiting treatment efficacy or tolerability. It should be taken into account that pharmacokinetic interactions may occur by competition in absorption, metabolic processes, and excretion. Pharmacodynamic interactions may be caused in particular by concomitant medication which can also have additional anticholinergic potency. As shown by Sumukadas et al., the proportion of older people with a very high anticholinergic exposure increased from $7.3 \%$ in 1995 to $9.9 \%$ in 2010 [46]. It is known that a greater anticholinergic burden can lead to significant deficits in cognitive function [47].

\section{Muscarinic receptors}

Pharmacodynamic reasons for refractory $\mathrm{OAB}$ could also be based on the receptor level. Age-related decrease of muscarinic receptors in the urinary bladder has been shown in rats, but there were only minor, if any, alterations in receptor responsiveness [48]. In humans, a shift of $\mathrm{M}_{3}$ muscarinic receptor subtypes to $\mathrm{M}_{2}$ was observed in correlation with age and in patients with neurogenic bladder overactivity [32]. Whether such changes are of clinical relevance still remains to be clarified.

All the described factors may necessitate adjustment of individual doses in antimuscarinic treatment. A decrease of the daily dose may be an option especially in elderly patients when side effects become problematic, as physiological changes connected with aging may result in reduced metabolism, alterations in distribution, declined excretion, and a decline in counter-regulatory mechanisms [45].

Pharmacological management of patients not responding to first-line therapy

Generally, flexible dosing with antimuscarinics provides the opportunity to increase or decrease the dose to meet the body habitus and the pharmacokinetic and clinical needs of the individual patients, thereby balancing efficacy against tolerability [49]. In connection with this, discussion and exchange of information between the physician and patient are a definite requirement to define the individual dose.

Data collected from non-interventional studies show that flexible dosing of trospium chloride adjusted to the patient's individual needs is commonly used in urological practices in Germany (Fig. 1) (data on file, 2014 Dr. R. Pfleger GmbH, Bamberg, Germany).

In patients who failed to respond, or showed suboptimal response to antimuscarinic drugs but tolerated the treatment well, it was shown that an increase of the daily dose may lead to a significant improvement of the OAB symptoms. A significant decrease of incontinence episodes was observed after doubling the recommended daily doses of trospium chloride and tolterodine to 90 and $8 \mathrm{mg}$, respectively, in patients with persistent neurogenic detrusor overactivity (NDO) [8]. An alternative approach is the combination of two different antimuscarinic drugs, which has been demonstrated as effective and safe in several clinical studies including patients with either OAB or NDO [7, 50-53]. Combination of an antimuscarinic with a beta-3 agonist has previously been investigated in clinical studies (Table 4) [6, 54].

When assessing these study results in patients with refractory $\mathrm{OAB}$, after doubling the recommended dose, or after combination treatment with a second drug, or after replacement by another antimuscarinic, one should consider that the situation of the unsatisfactory response to behavioral and antimuscarinic therapy is observed during daily routine medical practice. Patients with $\mathrm{OAB}$ who are included in clinical trials receive more intensive monitoring of their treatment. Motivation of patients with OAB may be increased by a defined regular follow-up appointment during clinical studies, and specified selection criteria could lead to a relatively homogeneous patient population. Consequently, symptom improvement in such clinical trials may not be reproducible
Fig. 1 Different daily doses of trospium chloride immediate release tablets prescribed by German urologists in 9,366 patients with $\mathrm{OAB}$ symptoms in medical practices. Pooled data from three non-interventional studies carried out in Germany (data on file, 2014, Dr. R. Pfleger $\mathrm{GmbH}$, Bamberg, Germany)

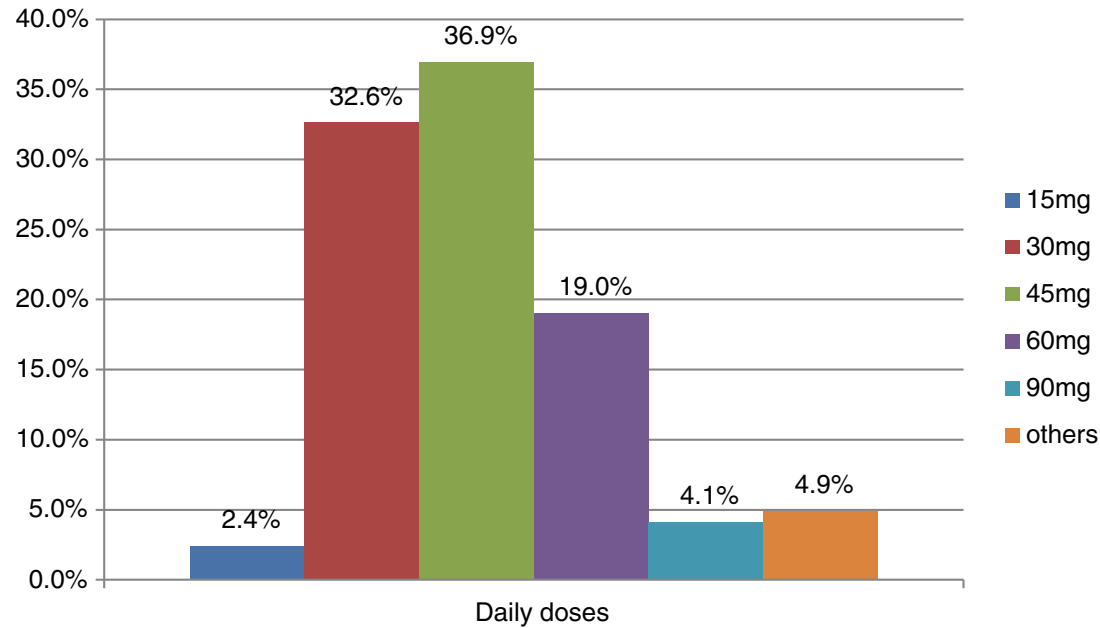


Table 4 Clinical studies using increased [8] or combined antimuscarinic treatment in patients with unsatisfactory benefit of previous/initial therapy

\begin{tabular}{|c|c|c|c|c|}
\hline Medication at start of therapy & Adjustment and dose/day & Patients $(n)$ & Efficacy results & Reference \\
\hline Tolterodine $1 \times 4 \mathrm{mg} /$ day $(n=11)$ & Tolterodine $2 \times 4 \mathrm{mg} /$ day $(n=11)$ & \multirow[t]{2}{*}{ NDO (21) } & \multirow{2}{*}{$\begin{array}{l}\text { In total UI episodes decreased } \\
\text { from } 8-12 \text { to } 0-2\end{array}$} & \multirow[t]{2}{*}{ Horstmann et al. $[8]$} \\
\hline Trospium $3 \times 15 \mathrm{mg} /$ day $(n=10)$ & Trospium $3 \times 30 \mathrm{mg} /$ day $(n=10)$ & & & \\
\hline Oxybutynin $30 \mathrm{mg} /$ day & Plus trospium $45-90 \mathrm{mg}$ & \multirow[t]{4}{*}{ NDO (27) } & UI episodes decreased: & \multirow[t]{4}{*}{ Amend et al. [50] } \\
\hline Tolterodine $2 \times 8 \mathrm{mg} /$ day & Plus oxybutynin $15-30 \mathrm{mg}$ & & From $8.6 \pm 2.7$ to $1.3 \pm 0.9$ & \\
\hline Trospium $3 \times 30 \mathrm{mg}$ & Plus tolterodine $4-8 \mathrm{mg}$ & & From $7.0 \pm 1.5$ to $0.6 \pm 0.7$ & \\
\hline & & & From $7.5 \pm 2.7$ to $2.0 \pm 1.5$ & \\
\hline \multirow[t]{4}{*}{ Tolterodine $4 \mathrm{mg}$} & Plus solifenacin $5 \mathrm{mg}$ & \multirow[t]{4}{*}{ NDO (19)/OAB (14) } & UI episodes decreased: & \multirow[t]{4}{*}{ Bolduc et al. [53] } \\
\hline & Plus solifenacin $10 \mathrm{mg}$ & & By $100 \%$ in 17 patients & \\
\hline & & & By $>90 \%$ in 14 patients & \\
\hline & & & By $50-89 \%$ in 2 patients & \\
\hline Oxybutynin $15 \mathrm{mg} /$ day & Plus trospium $80 \mathrm{mg}$ & \multirow[t]{3}{*}{ NDO (12) } & Decrease of UI episodes: & \multirow[t]{3}{*}{ Nardulli et al. [52] } \\
\hline \multirow[t]{2}{*}{ Oxybutynin $15 \mathrm{mg} /$ day } & \multirow[t]{2}{*}{ Plus solifenacin $10 \mathrm{mg}$} & & From $5.3 \pm$ SD to $0.8 \pm \mathrm{SD}$ & \\
\hline & & & From $4.5 \pm \mathrm{SD}$ to $1.0 \pm \mathrm{SD}$ & \\
\hline Oxybutynin or & Plus tolterodine ER $4 \mathrm{mg}$ or & \multirow{4}{*}{$\begin{array}{c}\mathrm{NDO} / \mathrm{OAB} \\
(31 / 25)\end{array}$} & Decrease of UI episodes: & \multirow[t]{4}{*}{ Nadeau et al. [7] } \\
\hline \multirow[t]{3}{*}{ Tolterodine } & \multirow[t]{9}{*}{ Plus solifenacin $5 \mathrm{mg}$ or $10 \mathrm{mg}$} & & By $100 \%$ in 23 patients & \\
\hline & & & By $>90 \%$ in 18 patients & \\
\hline & & & By $50-89 \%$ in 15 patients & \\
\hline $\begin{array}{l}\text { Trospium } 60 \mathrm{mg} \text { plus } \\
\text { solifenacin } 20 \mathrm{mg} \text { (198) or }\end{array}$ & & $\mathrm{OAB}(313)$ & $\begin{array}{l}\text { Significant decrease in UI episodes } \\
\text { compared to placebo }\end{array}$ & Kosilov et al. [51] \\
\hline Placebo (115) & & & & \\
\hline Solifenacin $2.5,5$, or $10 \mathrm{mg}$ or & & \multirow[t]{4}{*}{ OAB (1306) } & Dose-response relationship for & \multirow[t]{4}{*}{ Abrams et al. [54] } \\
\hline Mirabegron 25 or $50 \mathrm{mg}$ or & & & MVV in all combination groups & \\
\hline Solifenacin + mirabegron, or & & & No significant changes in UI & \\
\hline Placebo & & & episodes compared to placebo & \\
\hline
\end{tabular}

$U I$ urinary incontinence, $N D O$ neurogenic detrusor overactivity, $O A B$ overactive bladder (number of patients in parentheses), $E R$ extended release, $M V V$ volume voided per micturition

during clinical practice, when antimuscarinic treatment is not accompanied by close patient guidance [6]. This also applies to trials involving patients with refractory $\mathrm{OAB}$, where treatment with an antimuscarinic drug was replaced by another antimuscarinic or a beta-3 agonist, such as mirabegron $[6,9]$.

However, dose adjustment, the combination of two different antimuscarinic drugs, and replacement by another antimuscarinic or a beta-3 agonist are options in order to improve treatment success in individual patients with OAB. Selection of the best tolerated drug is of great importance to avoid unnecessary side effects. Especially in older patients where co-medication can have its own anticholinergic effects and/or compete in metabolism in the cytochrome P450 system, impairment of cognitive function as a side effect, and metabolic interactions, can largely be avoided by choosing an appropriate antimuscarinic such as the quaternary molecule trospium chloride, which does not seem to contribute to such effects [55-58] and enables flexible dosing.

In patients in whom critical reassessment of diagnosis leads to an exclusion of underlying causes for lower urinary tract dysfunction and who do not respond to intensive first-line therapy including adjusted antimuscarinic treatment, the use of transcutaneous electrical nerve stimulation, the intravesical administration of onabotulinumtoxinA injections, or augmentation cystoplasty may be further treatment options [59].

\section{Conclusion}

The incidence of refractory $O A B$ seems to be overestimated. An unsatisfactory improvement of symptoms in the first-line treatment option of patients with $\mathrm{OAB}$ may depend on various factors. Realistic estimation of treatment outcomes and side effects by the patient and/or the physician, individual patient guidance to improve the patient's motivation to adhere to treatment, review of the $\mathrm{OAB}$ diagnosis, and exclusion of other underlying causes as well as individual antimuscarinic dose adjustment are procedures which can improve the success of OAB therapy in daily medical practice. The authors suggest using the term refractory $\mathrm{OAB}$ only in such cases when the aforementioned steps have confirmed the patient's nonresponse to first-line treatment including antimuscarinic therapy.

Acknowledgments The authors would like to thank Anna Wolf(Dr. R. Pfleger $\mathrm{GmbH}$ ) for proofreading the manuscript.

Conflicts of interest Ulrich Schwantes is an executive employee of Dr. R. Pfleger GmbH, Joachim Grosse received research funds from Dr. R. Pfleger GmbH, and Andreas Wiedemann is a consultant of Dr. R. Pfleger $\mathrm{GmbH}$.

Authors' contributions Ulrich Schwantes carried out the literature search and writing of the draft manuscript. Joachim Grosse and Andreas 
Wiedemann contributed to the article by critical revision of the manuscript.

Open Access This article is distributed under the terms of the Creative Commons Attribution License which permits any use, distribution, and reproduction in any medium, provided the original author(s) and the source are credited.

\section{References}

1. Gormley EA, Lightner DJ, Burgio KL, Chai TC, Clemens JQ, Culkin DJ, Das AK, Foster HE Jr, Scarpero HM, Tessier CD, Vasavada SP et al (2012) Diagnosis and treatment of overactive bladder (nonneurogenic) in adults: AUA/SUFU guideline. J Urol 188(6 Suppl): 2455-2463. doi:10.1016/j.juro.2012.09.079

2. Lucas MG, Bedretdinova D, Bosch JLHR, Burkhard F, Cruz F, Nambiar AK, Nilsson CG, De Ridder DJMK, Tubaro A, Pickard RS (2014) EAU guidelines on urinary incontinence. European Association of Urology. Available via http://www.uroweb.org/gls/ pdf $/ 20 \% 20$ Urinary\%20Incontinence LR.pdf. Accessed 4 Sep 2014

3. Bosch JL, Groen J (2000) Sacral nerve neuromodulation in the treatment of patients with refractory motor urge incontinence: long-term results of a prospective longitudinal study. J Urol 163(4):1219-1222

4. Goldman HB, Wyndaele JJ, Kaplan SA, Wang JT, Ntanios F (2014) Defining response and non-response to treatment in patients with overactive bladder: a systematic review. Curr Med Res Opin 30(3): 509-526. doi:10.1185/03007995.2013.860021

5. Flynn MK, Amundsen CL, Perevich M, Liu F, Webster GD (2009) Outcome of a randomized, double-blind, placebo controlled trial of botulinum A toxin for refractory overactive bladder. J Urol 181(6): 2608-2615. doi:10.1016/j.juro.2009.01.117

6. Balachandran A, Curtiss N, Basu M, Duckett J (2015) Third-line treatment for overactive bladder: should mirabegron be tried before intravesical botulinum toxin A therapy? Int Urogynecol J 26(3):367372. doi:10.1007/s00192-014-2462-2

7. Nadeau G, Schröder A, Moore K, Genois L, Lamontagne P, Hamel M, Pellerin E, Bolduc S (2014) Double anticholinergic therapy for refractory neurogenic and nonneurogenic detrusor overactivity in children: long-term results of a prospective open-label study. Can Urol Assoc J 8(5-6):175-180. doi:10.5489/cuaj.1362

8. Horstmann M, Schaefer T, Aguilar Y, Stenzl A, Sievert K-D (2006) Neurogenic bladder treatment by doubling the recommended antimuscarinic dosage. Neurourol Urodyn 25(5):441-445

9. Wong C, Duggan P (2009) Solifenacin for overactive bladder in women unsuccessfully treated with immediate release oxybutynin: a pilot study. J Obstet Gynaecol 29(1):31-34. doi:10.1080/ 01443610802628726

10. Kaplan SA, Cardozo L, Herschorn S, Grenabo L, Carlsson M, Arumi D, Crook TJ, Whelan L, Scholfield D, Ntanios F et al (2014) Efficacy and safety of fesoterodine $8 \mathrm{mg}$ in subjects with overactive bladder after a suboptimal response to tolterodine ER. Int J Clin Pract 68(9): 1065-1073. doi:10.1111/ijcp. 12464

11. Swartz M, Vasavada S (2009) Diagnosing, treating refractory OAB. Renal and Urology News. Available via http://www. renalandurologynews.com/diagnosing-treating-refractory-oab/ article/129979/. Accessed 3 Sep 2014

12. Benner JS, Nichol MB, Rovner ES, Jumadilova Z, Alvir J, Hussein M, Fanning K, Trocio JN, Brubaker L (2010) Patient-reported reasons for discontinuing overactive bladder medication. BJU Int 105(9):1276-1282. doi:10.1111/j.1464-410X.2009.09036.x

13. Kuo HC (2011) Bladder base/trigone injection is safe and as effective as bladder body injection of onabotulinumtoxinA for idiopathic detrusor overactivity refractory to antimuscarinics. Neurourol Urodyn 30(7):1242-1248. doi:10.1002/nau.21054

14. Chughtai B, Dunphy C, Lee R, Lee D, Sheth S, Marks L, Kaplan SA, Te AE (2014) Randomized, double-blind, placebo controlled pilot study of intradetrusor injections of onabotulinumtoxinA for the treatment of refractory overactive bladder persisting following surgical management of benign prostatic hyperplasia. Can J Urol 21(2): $7217-7221$

15. Kanagarajah P, Ayyathurai R, Caruso DJ, Gomez C, Gousse AE (2012) Role of botulinum toxin-A in refractory idiopathic overactive bladder patients without detrusor overactivity. Int Urol Nephrol 44(1):91-97. doi:10.1007/s11255-011-9979-9

16. Marinkovic SP, Rovner ES, Moldwin RM, Stanton SL, Gillen LM, Marinkovic CM (2012) The management of overactive bladder syndrome. BMJ 344:e2365. doi:10.1136/bmj.e2365

17. Duthie JB, Vincent M, Herbison GP, Wilson DI, Wilson D (2011) Botulinum toxin injections for adults with overactive bladder syndrome. Cochrane Database Syst Rev (12):CD005493. doi:10.1002/ 14651858.CD005493.pub3

18. Herbison GP, Arnold EP (2009) Sacral neuromodulation with implanted devices for urinary storage and voiding dysfunction in adults. Cochrane Database Syst Rev (2):CD004202. doi:10.1002/14651858. CD004202.pub2

19. Maserejian NN, Wager CG, Giovannucci EL, Curto TM, McVary KT, McKinlay JB (2013) Intake of caffeinated, carbonated, or citrus beverage types and development of lower urinary tract symptoms in men and women. Am J Epidemiol 177(12):1399-1410. doi:10.1093/ aje/kws411

20. Hampel C (2007) Long-term management of overactive bladder with antimuscarinic agents. Eur Urol Suppl 6(5):432-437

21. Jundt K, Schreyer K, Friese K, Peschers U (2011) Anticholinergic therapy: do the patients take the pills prescribed? Arch Gynecol Obstet 284(3):663-666

22. Drake MJ (2012) Male lower urinary tract symptoms associated with overactive bladder. Can Urol Assoc J 6(5 Suppl 2):S136-S137. doi: 10.5489/cuaj.12202

23. Robinson D, Giarenis I, Cardozo L (2013) The medical management of refractory overactive bladder. Maturitas 74(4):386-390. doi:10. 1016/j.maturitas.2013.01.012

24. Digesu GA, Sadenghi P, Sharma S, Puccini F, Tubaro A, Fernando R, Khullar V (2013) The importance of cystoscopy and bladder biopsy in women with refractory overactive bladder: the urogynaecologist's point of view? Eur J Obstet Gynecol Reprod Biol 169(2):408-411. doi:10.1016/j.ejogrb.2013.05.027

25. Liu HT, Jiang YH, Kuo HC (2013) Increased serum adipokines implicate chronic inflammation in the pathogenesis of overactive bladder syndrome refractory to antimuscarinic therapy. PLoS One 8(10): e76706. doi:10.1371/journal.pone.0076706

26. Liu HT, Lin H, Kuo HC (2011) Increased serum nerve growth factor levels in patients with overactive bladder syndrome refractory to antimuscarinic therapy. Neurourol Urodyn 30(8):1525-1529. doi: 10.1002/nau.21118

27. Vijaya G, Cartwright R, Derpapas A, Gallo P, Fernando R, Khullar V (2013) Changes in nerve growth factor level and symptom severity following antibiotic treatment for refractory overactive bladder. Int Urogynecol J 24(9):1523-1528. doi:10.1007/s00192-012-2038-y

28. Malhotra B, Darsey E, Crownover P, Fang J, Glue P (2011) Comparison of pharmacokinetic variability of fesoterodine vs. tolterodine extended release in cytochrome P450 2D6 extensive and poor metabolizers. Br J Clin Pharmacol 72(2):226-234. doi:10. $1111 / j .1365-2125.2011 .03948 . x$

29. Skerjanec A (2006) The clinical pharmacokinetics of darifenacin. Clin Pharmacokinet 45(4):325-350

30. Douchamps J, Derenne F, Stockis A, Gangji D, Juvent M, Herchuelz A (1988) The pharmacokinetics of oxybutynin in man. Eur J Clin Pharmacol 35:515-520 
31. Simon HU, Malhotra B (2009) The pharmacokinetic profile of fesoterodine: similarities and differences to tolterodine. Swiss Med Wkly 139(9-10):146-151, doi:smw-12542

32. Wiedemann A, Schwantes PA (2007) Antimuscarinic drugs for the treatment of overactive bladder: are they really all the same ? A comparative review of data pertaining to pharmacological and physiological aspects. Eur J Geriatr 9(Suppl1):29-42

33. Geyer J, Gavrilova O, Petzinger E (2009) The role of P-glycoprotein in limiting brain penetration of the peripherally acting anticholinergic OAB drug trospium chloride. Drug Metab Dispos 37(7):1371-1372

34. Bexten M, Oswald S, Grube M, Jia J, Graf T, Zimmermann U, Rodewald K, Zolk O, Schwantes U, Siegmund W, Keiser M (2015) Expression of drug transporters and drug metabolizing enzymes in the bladder urothelium in man and affinity of the bladder spasmolytic trospium chloride to transporters likely involved in its pharmacokinetics. Mol Pharm 12:171-178

35. Lukkari E, Castrèn-Kortekangas $\mathrm{P}$, Juhakoski A, Löyttyniemi E, Aranko K, Neuvonen PJ (1996) Effect of food on the bioavailability of oxybutynin from a controlled release tablet. Eur J Clin Pharmacol 50:221-223

36. Sahlmann J, Clasen N, Schwantes U, Rachor D, Neumeister C, Schulz H-U (2010) Bioavailability of trospium chloride (TC) immediate release (IR) compared with an extended release (ER) form under everyday conditions. Eur Urol Suppl 9(6):620

37. Malhotra BK, Wood N, Sachse R (2009) Influence of age, gender, and race on pharmacokinetics, pharmacodynamics, and safety of fesoterodine. Int J Clin Pharmacol Ther 47(9):570-578

38. Hughes KM, Lang JCT, Lazare R, Gordon D, Stanton SL, MaloneLee JG, Geraint M (1992) Measurement of oxybutynin and its Ndesethyl metabolite in plasma, and its application to pharmacokinetic studies in young, elderly and frail elderly volunteers. Xenobiotica 22(7):859-869

39. Krauwinkel WJJ, Smulders RA, Mulder H, Swart PJ, TaekemaRoelvink MEJ (2005) Effect of age on the pharmacokinetics of solifenacin in men and women. Int J Clin Pharmacol Ther 43(5): 227-238

40. Wefer J, Truss MC, Jonas U (2001) Tolterodine: an overview. World J Urol 19(5):312-318

41. Doroshyenko O, Jetter A, Odenthal KP, Fuhr U (2005) Clinical pharmacokinetics of trospium chloride. Clin Pharmacokinet 44(7):701720

42. Kerbusch T, Wählby U, Milligan PA, Karlsson MO (2003) Population pharmacokinetic modelling of darifenacin and its hydroxylated metabolite using pooled data, incorporating saturable firstpass metabolism, CYP2D6 genotype and formulation-dependent bioavailability. Br J Clin Pharmacol 56(6):639-652

43. Lukkari E, Hakonen T, Neuvonen PJ (1998) The pharmacokinetics of oxybutynin is unaffected by gender and contraceptive steroids. Eur J Clin Pharmacol 53:351-354

44. Guay DRP (1999) Tolterodine, a new antimuscarinic drug for treatment of bladder overactivity. Pharmacotherapy 19(3):267-280

45. Turnheim K (2003) When drug therapy gets old: pharmacokinetics and pharmacodynamics in the elderly. Exp Gerontol 38:843-853

46. Sumukadas D, McMurdo MET, Mangoni AA, Guthrie B (2014) Temporal trends in anticholinergic medication prescription in older people: repeated cross-sectional analysis of population prescribing data. Age Ageing 43(4):515-521

47. Ancelin ML, Artero S, Portet F, Dupuy A-M, Touchon J, Ritchie K (2006) Non-degenerative mild cognitive impairment in elderly people and use of anticholinergic drugs: longitudinal cohort study. BMJ 332:455-459

48. Schneider T, Hein P, Michel-Reher MB, Michel MC (2005) Effects of ageing on muscarinic receptor subtypes and function in rat urinary bladder. Naunyn Schmiedebergs Arch Pharmacol 372(1):71-78

49. Chapple CR, Rosenberg MT, Brenes FJ (2009) Listening to the patient: a flexible approach to the use of antimuscarinic agents in overactive bladder syndrome. BJU Int 104(7):960-967

50. Amend B, Hennenlotter J, Schäfer T, Horstmann M, Stenzl A, Sievert K-D (2008) Effective treatment of neurogenic detrusor dysfunction by combined high-dosed antimuscarinics without increased side-effects. Eur Urol 53(5):1021-1028

51. Kosilov K, Loparev S, Iwanowskaya M, Kosilova L (2014) Effectiveness of combined high-dosed trospium and solifenacin depending on severity of OAB symptoms in elderly men and women under cyclic therapy. Cent European J Urol 67(1):43-48. doi:10. 5173/ceju.2014.01.art9

52. Nardulli R, Losavio E, Ranieri M, Fiore P, Megna G, Bellomo RG, Cristella G, Megna M (2012) Combined antimuscarinics for treatment of neurogenic overactive bladder. Int J Immunopathol Pharmacol 25(1 Suppl):35S-41S

53. Bolduc S, Moore K, Lebel S, Lamontagne P, Hamel M (2009) Double anticholinergic therapy for refractory overactive bladder. J Urol 182(4 Suppl):2033-2038. doi:10.1016/j.juro.2009.05.099

54. Abrams P, Kelleher C, Staskin D, Rechberger T, Kay R, Martina R, Newgreen D, Paireddy A, van Maanen R, Ridder A (2014) Combination treatment with mirabegron and solifenacin in patients with overactive bladder: efficacy and safety results from a randomised, double-blind, dose-ranging, phase 2 study (symphony). Eur Urol. doi:10.1016/j.eururo.2014.02.012

55. Diefenbach K, Donath F, Maurer A, Quispe-Bravo SDW, Schwantes U, Haselmann J, Roots I (2003) Randomised, double-blind study of the effects of oxybutynin, tolterodine, trospium chloride and placebo on sleep in healthy young volunteers. Clin Drug Investig 23(6):395404

56. Diefenbach K, Arold G, Wollny A, Schwantes U, Haselmann J, Roots I (2005) Effects on sleep of anticholinergics used for overactive bladder treatment in healthy volunteers aged $>50$ years. BJU Int 95(3):346-349

57. Kranz J, Petzinger E, Geyer J (2011) Brain penetration of the OAB drug trospium chloride is not increased in aged mice. World J Urol 31:219-224

58. Staskin D, Kay G, Tannenbaum C, Goldman HB, Bhashi K, Ling J, Oefelein MG (2010) Trospium chloride has no effect on memory testing and is assay undetectable in the central nervous system of older patients with overactive bladder. Int J Clin Pract 64(9):12941300. doi:10.1111/j.1742-1241.2010.02433.x

59. Wadie BS (2014) Management of refractory OAB in the nonneurogenic patient. Curr Urol Rep 15(9):438. doi:10.1007/s11934014-0438-x 